DOI: $10.31866 / 2410-1915.21 .2020 .208235$

UDC 78.031.4(510)

\title{
CHINESE MUSICAL TRADITIONS: STAGES OF DEVELOPMENT
}

\author{
Maryna Antoshko \\ PhD in Art Studies, \\ ORCID: 0000-0002-4105-7519, antoshko.m@rambler.ru, \\ Ukrainian National Tchaikovsky Academy of Music, \\ 1-3/1, Horodetskoho St., Kyiv, 02000, Ukraine
}

\section{For citations:}

Antoshko, M. (2020). Chinese Musical Traditions: Stages of Development. Culture and Arts in the Modern World, 21, 11-22. https://doi.org/10.31866/2410-1915.21.2020.208235.

The purpose of the article is to analyse the development of the worldview system of Ancient China, in particular, the philosophy that directly determined the cultural and musical traditions of the country. The research methodology provides historical and biographical methods for the subject studying. We have researched the effects of the worldview of Ancient China on the country's musical traditions. Furthermore, we have defined the historical names of philosophers who influenced the development of musical art and education mostly, which also affected cultural traditions. Conclusions. Chinese musical culture has been proven to be originated from the performance of ritual song and dance rites during work, then it was repeated in court and temple traditions. As a result, by the time of the early Western Zhou period (the $11^{\text {th }}-3^{\text {rd }}$ centuries BC), a music institution was created, which started a school of music and dance. Music took a philosophical content in the late Eastern Zhou period (770 - 256 BC) following the emergence and spread of Confucianism and Taoism. During the Han period, due to the cultural influence of India and other Middle Eastern countries, Buddhism spread in China, and new musical instruments appeared. In the $6^{\text {th }}-7^{\text {th }}$ centuries, musical compositions for qin and pipa were composed, written in the form of dialogues that included songs and dances; the role of the orchestral part began to grow. During the $11^{\text {th }}-13^{\text {th }}$ centuries, musical styles were divided into northern (heroic moods, heptatonic scales) and southern (strict rules of composition, pentatonic scales). Since the $17^{\text {th }}$ century, Chinese music has been introduced as folk songs. Jingju theatre performances became popular. Shi fan xue orchestra music was actively developing. In the $18^{\text {th }}$ and $19^{\text {th }}$ centuries, Chinese musicians did already use the European instruments and perform European music. Changes have been taking place in the vocal art, where the socalled musical form tanci has appeared.

In the $20^{\text {th }}$ century, Chinese professional music was formed, and the system of music education was developed. There was a search in the musical style in order to emphasise the national basis. Chinese composers in their original works combine national and stylistic origins with models of European music, thus creating their own nationally coloured style.

Keywords: worldview system of China; musical art; cultural traditions; philosophy of the country. 


\section{Introduction}

Chinese culture is one of the oldest in the world. It is known that in the course of cultural development art is separated from philosophy into a particular form of social life - spiritual while maintaining sense connections and mutual influences with worldview sciences and institutions, since under the influence of art in general and music in particular, the artistic consciousness of the society and the ability to treat social and natural phenomena creatively are developed. Value orientations, norms, and ideals are formed. The formation of Chinese musical traditions is organically and very closely linked to the development of the country's philosophy and history. In recent decades, the country's culture has aroused increasing interest among researchers due to the fundamentally new role that China plays in the modern world. Therefore, the study of the worldview system of China is relevant because it determines the return to the philosophical origins that contributed to the formation and development of Chinese musical culture.

The issue of the worldview system of Ancient China and its culture has always attracted the attention of researchers. In particular, V. Sidikhmenov (1987) based on literary and documentary sources describes the Chinese people's vision of the world, the basis of religious life and the education system during the reign of the Qing dynasty $\left(17^{\text {th }}-\right.$ early $20^{\text {th }}$ centuries). L. Perelomov (2000) studied the influence of Confucianism on the spiritual and political culture of the countries of the Asia-Pacific region. The name of U Gen-Ir should be mentioned among the Chinese scientists who studied the Asian culture and lived in the territory of China at that time (U Gen-Ir, 2011). K. Ha Poong (Ha Poong Kim, 2016) researched folk songs of the most famous anthology "Shi Jing”. This work is a translation of its first part, namely the songs of Guo Feng. Canadian scholar William Baxter (Baxter, 1991) devoted his research to the issue of the language of ancient Chinese texts. I. Lisevich (1969) in her monograph analysed the ancient Chinese poetry Yuefu, as well as the evolution of artistic means, some features of classical Chinese poetry.

\section{Purpose of the article}

The purpose of the article is to analyse the development of the worldview system of Ancient China, in particular, the philosophy that directly influenced the country's cultural and musical traditions, tracking the development in the sequence of specific historical periods. The purpose of the article is achieved by using historical and biographical methods, which made it possible to trace the formation and development of musical traditions in the later historical epochs, as well as the influence of religious and philosophical systems and individuals on the music of China.

\section{Main research material}

The roots of Chinese culture come from the early Paleolithic period to the formation of the Shang-Yin state (approximately 1766 - $1027 \mathrm{BC}$ ). Chinese mu- 
sical culture was developed in connection with the cultures of South, Central and Western Asia.

The ethnic composition of the population of the ancient Chinese state was heterogeneous since the Chinese nation was formed in the conditions of close contacts of the local people with the Tungus, Manchus, Mongols, Tibetans, Burmese, Indochina tribes and other nomadic neighbours. Therefore, the syncretism of the Iranian, Chinese, Sogdian and Turkic cultural traditions can be observed in the works of art. In the course of historical development, Chinese music has absorbed elements of the musical cultures of peoples who were part of the Chinese state in different historical periods.

The first definition of the term "music" in most modern dictionaries, such as explanatory or the one of foreign words, etc., is the following: it is an art that reflects the reality in sound artistic images. This interpretation corresponds to the Chinese term "yinyue", which means "the art of sounds". In ancient China, the concept of "music" had a slightly different meaning. By "music" (yue) they meant a ritual dance to the accompaniment of musical instruments. Every note, every musical rhythm, the smallest gesture of a dancer symbolised something. Encoded in the language of music and dance, the Chinese told stories from the lives of legendary heroes, reproduced vivid historical subjects, and expressed their attitude to the political life of the country. There was a direct connection between the nature of music and the state of society at that time. (A certain separation of music into an independent art form, in "yinyue", occurred at the end of the Zhou era). It is no coincidence that in many ancient chronicles there are such phrases as "yuevu" (music and dance), "gevu” (song and dance), which indicate the ancient forms of Chinese musical culture.

According to traditional religious and philosophical concepts, the ancient Chinese associated each degree of the scale, sound with a certain time of year, time of day, the position of the Sun and Moon, various birds and animals, elements of nature, and so on. Some tunes were performed in spring, others - in summer, autumn, and winter.

Certain periods of development with their own characteristic features have been identified in the history of Chinese musical culture. The first of them was the music of Ancient China when the formation of Chinese music took place. Its approximate chronological boundaries are from the $20^{\text {th }}$ century $\mathrm{BC}$ to the $3^{\text {rd }}$ century AD. The next period is the music of China's early medieval period, which is characterised by the enrichment of foreign influences and prosperity. It lasted from the $3^{\text {rd }}$ century $\mathrm{BC}$ to the beginning of the $13^{\text {th }}$ century AD. The period of maturity of Chinese music is considered to be the late Middle Ages (from the beginning of the $13^{\text {th }}$ century to 1911). The period from 1911 to the present is the music of Modern times (U Gen-Ir, 2011, pp. 22-23).

The period of Ancient China was preceded by the Archaic epoch $\left(26^{\text {th }}-\right.$ $21^{\text {st }}$ centuries BC). In the territories of Henan, Shaanxi and Shanxi, there was a cult associated with singing and dancing, dedicated to the beginning and end of the harvest. Religious song-and-dance rituals honouring the gods and spirits of ancestors were widespread for the entire next season. 
The right to perform sacrificial ceremonies to Heaven and ancestors belonged exclusively to the aristocracy. The status of each rank of dignitaries was determined by the system of inheritance of power. Bronze dishes and musical instruments were the material expressions of this status. These items symbolised the connection between a man and the Heavens, a man and a deity (shen), and were used in ceremonies of sacrifice to Heaven in the ancestral temples. Confucius (Confucius, 2002) noted the importance of the ritual and emphasised that it defines the differences between people, while music unites them. It was music that the philosopher considered the beginning of spiritual perfection, the inner image of the ritual. The system of music and ritual was actually one of the foundations of China's political system at that period, and the ritual bronze objects of the pre-Qing period were its symbol.

Chinese rulers, including Fuxi and Shennong, played musical instruments, which they created themselves, considering music as a means of communicating between the forces of nature (for example, Heaven and Earth). Musical folk art was also in the process of development - any work was accompanied by singing and dancing.

The musical culture of the Shan-Yin State $\left(16^{\text {th }}-11^{\text {th }}\right.$ centuries BC) was built on the ritual song and dance rites dedicated to the harvest and sacrifices to the gods. Later, this combination of arts was recreated in the court and temple traditions. The first musical instruments were found during the excavations (the first half of the $20^{\text {th }}$ century) in Henan province: tsin - a single stone slab, zhong - an iron bell, syuan - a clay spherical tool with holes that served as a wind instrument.

We should also note the peculiarities of the Chinese musical language, built on the monophony with the elements of heterophony. The rhythm is simple, which is repeated in some places. High notes are the characteristic feature of Chinese music and singing is characterised by a falsetto, guttural manner. Later, the main features of secular music begin to form - a combination of singing, music and dance (U Gen-Ir, 2011, p. 26).

The Zhou era $\left(11^{\text {th }}-3^{\text {rd }}\right.$ centuries $\left.B C\right)$ was characterised by the rise of all branches of culture. There are Early (Western) Zhou (11 ${ }^{\text {th }}$ century $\left.-770 \mathrm{BC}\right)$ and Late (Eastern) $(770-256 \mathrm{BC})$. Realising the influence and role of music in the society, representatives of the Zhou dynasty resorted to the organisation and development of this art. In the early Zhou era, a Music institution appeared, thanks to which a music school for music and dance training was opened. The training lasted seven years, usually for students aged 13 to 20 years. An important element was that the teaching distinguished between court and folk music; in other words, there was a certain classification of music, the division into right and wrong. There were clear rules for conducting ceremonies with the definition of status, according to which the number of orchestras and musicians was regulated. Thus, the number of orchestras depended on the rank of the person for whom the ceremony was held: four orchestras were allocated for the emperor, three for the prince or feudal lord, two - for high-ranking officials, and one for ordinary officials and scholars. The number of dancers followed the same principle. These rules were further improved with the de- 
velopment of "yayue" - the right music. At this time, the number of musical instruments began to increase. The appearance of the stringed instrument qin (zither) also belongs to this epoch. The pentatonic scale was used, as well as Lydian scale (U Gen-Ir, 2011, p. 28).

In the late Zhou period, a philosophical attitude to the interaction of music and social processes was formed. This is mostly due to the works of Confucius (Kung Fu-tzu, 551 - 479 BC), namely: "Shi Jing" ("Book of Songs"), "I Jing" ("Book of Changes"), "Chunqiu" ("Spring and Autumn Annals"), "Li Ji" ("the Book of Rites"). The book "The Lunyu" ("The Analects of Confucius") is of our concern and reflects the philosophical thought of Confucius. In his opinion, the music combines the feminine and masculine elements, reflects the harmony in nature; that is, it has cosmological properties. On the other hand, music has an important mission in the process of governing the country, because being harmonious, it affects the moral qualities of a person and social norms. The ideology of the Chinese philosopher Confucius, which guided the ancient and next rulers of China, largely contributed to the fact that music became a state cult and had a state significance: it was a means to influence the people's customs and moods, control people, keep them in obedience. The attitude of Confucianism and the state to music can be considered as one of the main specific features of Chinese civilisation.

"Shi Jing" ("The Book of Songs"), compiled by the philosopher, is the oldest and most revered work of Chinese literature. "Shi Jing" is preserved mainly in two works. The earliest (2000 - 1000 BC) - in "The Book of Songs", in the collections of the Music Bureau (1000 BC - the first centuries AD) (Lisevich, 1969, p. 23).

Professor at the University of Berlin Wilhelm Grube in his article "Die Chinesische Literatur chinesische Literatur" wrote that "Shi Jing" belongs to the precious poetic treasures of antiquity and is entitled to an honourable place in world literature" (Grube, 1932, p. 23). Swedish academician B. Karlgren, in his comments in 1964 to his exemplary translation of "Shi Jing", noted that this work "by importance and influence on the following centuries could not compete with any work in the history of Chinese literature" (Karlgren, 1964, p. 71). In China, this poetic canon has been commented on and studied for more than two millennia, and in the West, it has been translated and studied for almost 300 years. However, it is still full of unexplained places and meaningful mysteries (Kobzev, 2018, p. 261).

"Shi Jing" contains three hundred and five poetic works and consists of four sections or parts:

"Guó fēng" ("Airs of the States") - works collected from fifteen different kingdoms of China at the time;

"Xiǎo yă" ("Lesser Court Hymns") - created by court poets;

"Dà yă" ("Major Court Hymns") - a book of poetic works of the Zhou tribe; (Shāng sòng - "Hymns") - temple songs and cult hymns in honour of the spirits, ancestors and wise kings of Chinese antiquity.

The first part crystallises the songs of the southern regions of China, which are about 60 . The second and third parts combine the works of court authors. 
The fourth part highlights the hymns that glorify the activities of ancestors and kings. This form of ancient Chinese rhyming required song and vocal performance. Later, the traditions outlined in the "Shi Jing" became spread in Japan, Korea, and other countries and influenced their culture.

Important information about the art of music is contained in the treatise "Guan-Tzu", the author of which, according to Chinese tradition, is considered Guan Zhong (most modern Chinese scholars believe that the work was written after his life). "Guan-Tzu" represented the economic, social and political reforms that Guan Zhong had carried out while serving as the Chief Minister of the State of Qi (Tcyrenov, 2007). The first mention of the "lui" concept can be found in the treatise, which was associated with the numerical expression of each sound in the pentatonic scale and the possibilities of the mode creation. (U Gen-Ir, 2011, p. 35).

Folk songs "Minge" appeared in the late Zhou era due to the combination of the musical culture of different ethnic groups that lived in China. They also gave start to the writing of song suites. Thus, "Jiu Ge" ("Nine Songs") became the famous suite became, which includes 11 songs of the southern Chinese origin of the Chu Kingdom (now the territory of Hunan province). The characteristic feature of this work is the same melodic line. "Jiu Ge" was performed to the spirits of nature (Heaven, God of rivers, God of longevity, Sun God, and others) as a sacrificial suite. The poet Qu Yuan (another name Qu Píng, 340 - 278 BC) worked on the texts of the songs. A collection of poems and songs "The Chu $\mathrm{Ci}$ " (Verses of Chu" or "Chronicle of the Chu Kingdom") appeared with the support of other poets led by Qu Yuan. The end of the Zhou era ( $3^{\mathrm{d}}$ century BC) brings another song and poetic genre - "shuochang yinyue" or "shuochang". There is a story and singing on the stage, accompanied by the music of a percussion instrument. These were the first examples of theatrical art. The founder of this musical genre is considered to be Xunzi (315 - 236 BC) (U Gen-Ir, 2011, p. 39). Xunzi believed that a person's musical expression needed to be regulated so that joy and liveliness would not turn into chaos. Therefore, during the process of music creation, it is crucial to focus on elegance and simplicity: clarity is essential for texts, and refinement and simplicity are important for melodies.

The Zhou period was followed by the Qin dynasty (221 - 206 BC). Qin Shi Huangdi ("the Divine Lord") self-invented title "emperor", who was one-person executive, carried out monetary and writing system reforms, drafted end standards of weight and length, built the Great Wall of China and about 300 palaces and temples. There was much done to uplift culture and art, on the other hand, during this period, Confucianism was deadly abolished, and its supporters were persecuted. In this period, orchestras and orchestral music got a lot of play.

In the Han period (206 BC - AD 220), which changed the Qin dynasty, Confucianism returned and remained the state ideology of China until the 1911 Xinhai Revolution. A significant event of this period for the development of music in the country was the founding of Yuefu, the Chinese Imperial Music Bureau in 112 BC. The term "yuefu" means "lyrics". There are ancient ritual chants, folk songs created in the Han period, author's songs in folkstyle (Kravtsova, 1983). The Bureau had musical groups that included singers and dancers from different 
regions of China (about 800 people). It dealt with all aspects of the Empire's musical life as researching, creativity, performance, and directing. The Bureau was charged to classify music and systematise the rules and procedures for performing sacred and social ceremonies. Ritual chants were created, folk songs were collected and processed. During this period, the author's songs in the folk style of different genres (love, labour, even rebellious) existed. In the late Han social songs, there were anacreontic and fairy-tale themes (Anuchyna, 2005). In the history of the Han dynasty, the Yuefu Music Bureau had existed for 106 years. In the years since, the tradition was maintained: in China, at the Imperial court, there were always specialised institutions that were concerned with the music.

From about the middle of the $3^{\text {rd }}$ century, Taoism had the greatest influence on Chinese culture, the founder of which is considered to be the old master Lao Tzu. At the focus of his doctrine is the concept of the Tao ("Path"), to which the whole world is subordinate and which is the basis and source of all things, constantly moving, obeying natural necessity. A person should not interfere with the natural course of life by their actions; otherwise, they will cause chaos. Taoism recognised the cosmological origin of music and its influence on nature. It was believed that culture, and music, in particular, can lead to a distortion of human nature, causing emotions, desires, thereby preventing the merging mentioned above with the Tao. Real music should bring a person to a state of purity and peace, and for this, the beauty of sound should be high, affirm the unity of nature and man (Vasilchenko, 2013).

The Great Silk Road and cultural exchange with the Middle East and India peoples contributed to the development and enrichment of Chinese music. New ideas, themes, and musical instruments were emerging in Chinese culture. The history of the Great Silk Road is also connected with the spread of Buddhism in China. The traditions of the Han Empire with its Confucian worldview, which incorporated many elements of other systems, did not give Buddhism enough space to spread successfully. As a result, Buddhism was adapted to the peculiarities of Chinese culture, and it became perceived by many as a system of views that does not contradict traditional Chinese ideology. New ties between China and other countries gave rise to the flourishing of folk music, especially folk songs. The song genre "xianghege" appeared, which collected all the songs of the peoples of North China. Qin music was actively developing and the foundations of "guchui" - military music by a trap brass orchestra. The melodies of military songs were based on folk melodies. Thus, the Chief musician of the Bureau, Li Yannian, composed "new songs" - "xin ge" for a military orchestra (U Gen-Ir, 2011, p. 48).

In the 6th century, "You Lan" or "Secluded Orchid" by the composer Qiu Ming was composed for the qin, and there was music in the form of dialogues that included Chinese songs and dances. An interesting musical manuscript for the pipa stringed instrument (the 7th century) was found in the Buddhist temple of Dunhuang. During this period, the role of the orchestral part was actively developing in music, and new musical instruments appeared. During the $13^{\text {th }}-$ $14^{\text {th }}$ centuries, two musical styles were distinguished: Northern (heroic moods, heptatonic scales) and southern music schools (strict rules of composition, 
pentatonic scales). Since the $17^{\text {th }}$ century, there had been certain democratisation of Chinese music, folk song culture and Jingjus, local theatre and music performances were actively developing. In the $18^{\text {th }}-19^{\text {th }}$ centuries, Shi fan xue orchestral music took an important place in China. There were European-type orchestras too.

At the beginning of the $20^{\text {th }}$ century, contacts with other countries were expanding. Musicians got music education in the European tradition outside of China. Most of them, having mastered Western professional music, remained under the influence of traditional Chinese music. The reform of school education in China (when music was first introduced as a compulsory subject in the curriculum) gave rise to the development of a new vocal genre - the School Song ("xuetang yuege"). After the 1911 Revolution, when the rule of the Qin dynasty was put to an end, the European music knowledge took place. The European notation system was being introduced, and attempts were being made to adapt Western music to Chinese culture. Since 1931, the military conflict with Japan had caused the rise of the Patriotic Movement in the circles of musicians and the creation of inyue, Patriotic songs. For song performance, there was a musical form of Tanci - a rhymed story with rhythmic figures, where the narration is together with singing and playing stringed musical instruments. Later, tanci followed modern forms of baojuan and various forms of dagu. In 1949 - 1956, China created a system of music education, started conservatories, and developed all areas of music. During this period, well-known composers Ding Shande, Li Yinghai, Lu Zhuang, Hubei Huang, Du Qian, Wang Peiyuan, Jiang Qu-Xin, San Tong, Wang Lishan, and others were actively working. (Den Kai Iuan, 2015). The period of the Cultural Revolution was quite difficult for the development of classical Chinese music. Unable to develop this direction, the musicians actively worked with folk songs and folklore of outlying provinces. Since the early 1970 s, there had been a return to traditional melodies from revolutionary songs based on slogans. In 1972, the anthology "New Songs of the Battlefield" was published, which became an annual publication in the next five years. The new reform policy of the government (the end of the 1970s) contributed to the emergence of a "new wave" in music, whose representatives, using Western methods of composition, originally reproduced the life of China, creating a modern musical style. Among the famous figures of the "new wave" were composers Zhao Xiaosheng, Wang Lixan, and Chuan Zhihao. Late $20^{\text {th }}-$ early $21^{\text {st }}$ century is rightly considered to be the golden period of all genres of Chinese professional music.

\section{Conclusions}

Therefore, the origins of Chinese musical culture are ritual song and dance rites dedicated to the harvest and sacrifice to the gods as a means of communicating with the forces of nature and later repeated in court and temple traditions. At the beginning musical instruments were the wind, and the Chinese musical language had a simple rhythm built on a single voice, then later social music occurred, where singing, music and dance were combined. As a result, by 
the time of the early Western Zhou period (the $11^{\text {th }}-3^{\text {rd }}$ centuries BC), a music institution was created, which started a school of music and dance. Music took a philosophical content in the late Eastern Zhou period (770 - $256 \mathrm{BC}$ ) following the emergence and spread of Confucianism and Taoism. In particular, Confucianism had the idea of a combination of female and male principles in music and little to reflect the harmony in nature. An important mission of music was seen in the state ruling, because it influenced the fostering of mores in society. Also, the founder of Taoism, Lao Tzu, professing spiritual self-improvement, simplicity and naturalness, believed that music should promote a positive emotional state of a person and a harmony with nature.

During the Han period, due to the cultural influence of India and other Middle Eastern countries, Buddhism spread in China, and new musical instruments appeared. During this period, Chinese musical culture was influenced by philosophical trends based on the Lao-Buddhist vision. They addressed research issues in music, namely classification (classical and folk), rules for conducting ceremonies and ritual rites. An outstanding achievement was the collection and adaptation of folk songs. There were new poetic genres as "yuefu", song genre "xianghege", backgrounds for military music "guchui".

In the $6^{\text {th }}-7^{\text {th }}$ century, music for qin and pipa was composed, and new forms of dialogue were used, including songs and dances. Orchestral parts were developing. There were new musical instruments. During the $11^{\text {th }}-13^{\text {th }}$ centuries, musical styles were divided into Northern (heroic moods, heptatonic scales) and southern (strict rules of composition, pentatonic scales). Since the $17^{\text {th }}$ century, Chinese music has been introduced as folk songs. Musical and theatrical performances jingju were getting popular. Orchestral music shi fan xue hold a high position. At the same time (the $18^{\text {th }}-19^{\text {th }}$ century), Chinese musicians adopted European instruments and performed European music following the colonisation policy. Changes had been taking place in the vocal art, where the so-called musical form tanci had appeared. In the $20^{\text {th }}$ century, Chinese professional music was formed, and the system of music education was developed. There was a search in the musical style to emphasise the national basis. Chinese composers in their original works combine national and stylistic origins with models of European music, thus creating their own nationally coloured style.

Chinese rulers have always recognised music as an essential component of social life, which directly shapes reality and plays a significant role in the organisation of society. That is why traditions in Chinese music are secular.

The issue of the influence of the worldview system of Ancient China on the music of Eastern countries also requires further study.

\section{References}

Anuchyna, L. V. (2005). Kultura Skhodu (davni tsyvilizatsii i serednovichchia) [Culture of the East (ancient civilisations and the Middle Ages)]. Rehion-inform [in Ukrainian].

Baxter, W. H. (1991). Zhou and Han phonology in the Shijing. In W. G. Boltz, \& M. C. Shapiro (Eds.), Studies in the Historical Phonology of Asian Languages (pp. 1-34). Benjamins [in English]. 
Confucius. (2002). Izrecheniia. Kniga pesen i gimnov [Sayings. Book of Songs and Hymns] (I. Semenenko, \& A. Shtukin, Trans.). Folio [in Russian].

Den Kai Iuan. (2015). Osobennosti natcionalnoi stilistiki v kamerno-vokalnoi muzyke kitaiskikh kompozitorov [Features of national stylistics in chamber-vocal music of Chinese composers]. The problems of interaction of art, pedagogic science, theory and practice of education, 44, 58-70 [in Russian].

Grube, W. (1932). Chinesische Literatur [Chinese literature]. Athenaion [in German]

Ha Poong Kim. (2016). Joy and sorrow: songs of ancient China: a new translation of Shi Jing Guo Feng. Sussex Academic Press [in English].

Karlgren, B. (1964). Glosses on the Book of Odes. Museum of Far Eastern Antiguities [in English].

Kobzev, A. I. (2018). Starye problemy i novyi perevod "Shi tczina" [Old problems and new translation of "Book of Poetry"]. Obshchestvo i gosudarstvo v Kitae, 48(2), 261331 [in Russian].

Kravtcova, M. E. (1983). Avtorskie "iuefu". K istorii razvitiia [Copyright "yuefu". To the history of development]. In Pismennye pamiatniki i problemy istorii kultury narodov Vostoka [Written monuments and problems of the history of culture of the peoples of the East] (Pt. 2, pp. 25-31). Nauka [in Russian].

Lisevich, I. S. (1969). Drevniaia kitaiskaia poeziia i narodnaia pesnia [Ancient Chinese poetry and folk song]. Nauka [in Russian].

Perelomov, L. S. (2000). Confucius: "Lun Iui" [Confucius: "Lun Yu". East literature]. Vostochnaia literatura [in Russian].

Sidikhmenov, V. Ia. (1987). Kitai: Stranitcy proshlogo [China: Pages of the Pas] (3 $3^{\text {rd }}$ ed.). Nauka [in Russian].

Tcyrenov, Ch. Tc. (2007). Drevnekitaiskii gosudarstvennyi deiatel Guan Zhong i odnoimennyi traktat "Guan-tczy" [The ancient Chinese statesman Guan Zhong and the treatise of the same name "Guan Tzu"]. In Istoriia i kultura narodov Sibiri, Stran Tcentralnoi i Vostochnoi Azii [History and culture of the peoples of Siberia, Central and East Asia] (pp. 451-469). ESSACA [in Russian].

U Gen-Ir. (2011). Istoriia muzyki Vostochnoi Azii (Kitai, Koreia, Iaponiia) [History of East Asian music (China, Korea, Japan)]. Planeta muzyki; Lan [in Russian].

Vasilchenko, E. V. (2013). Model mira v zvuchanii kitaiskoi tcitry tcin [A model of the world in the sound of Chinese qin zither]. Vestnik Rossiiskogo universiteta druzhby narodov. Seriia: Vseobshchaia istoriia, 1, 7-34 [in Russian]. 


\section{ЕТАПИ ФОРМУВАННЯ МУЗИЧНИХ ТРАДИЦІЙ КИТАЮ}

\section{Антошко Марина Олегівна}

Кандидат мистецтвознавства, ORCID: 0000-0002-4105-7519, antoshko.m@rambler.ru, Національна музична академія України імені П. І. Чайковського, Київ, Україна

Метою статті є аналіз розвитку світоглядної системи Стародавнього Китаю, зокрема філософії, що безпосередньо визначала культурні та музичні традиції країни. Методологія дослідження полягає у використанні історичного та біографічного методів у вивченні даної тематики. Досліджено дії світогляду Стародавнього Китаю на музичні традиції країни. Виокремлено історичні імена філософів, які найбільше вплинули на розвиток музичного мистецтва та освіти, що також позначилось на культурних традиціях.

Висновки. Доведено, що виникнення музичної культури Китаю спричинене виконанням ритуальних пісенно-танцювальних обрядів під час роботи, згодом вона відтворилася у придворних та храмових традиціях. Внаслідок цього було створене Музичне відомство, завдяки якому відкрили музичну школа з підготовки музики і танців в епоху Ранньої (Західної) Чжоу (11 - 3 ст. до н. е.). Філософського змісту музика почала набувати в епоху Пізньої (Східної) Чжоу (770 - 256 рр. до н. е.), чому сприяло виникнення та поширення конфуціанства і даосизму. В епоху Хань завдяки культурному впливу Індії та інших країн Близького Сходу в Китаї поширюється буддизм та з'являються нові музичні інструменти.

У 6 - 7 ст. складаються музичні твори для інструментів цинь і піпа, що пишуться у формі діалогів, які включають пісні та танці; починає зростати роль оркестрової партії. Протягом 11 - 13 ст. музичні стилі поділилися на північний (героїчні настрої, семиступеневі лади) та південний (суворі правила композиції, пентатонічні лади). Із 17 ст. китайська музика стає народнопісенною. Набувають популярності театральносценічні вистави - цзінцзюй. Активно розвивається оркестрове музикування - ши фань гу. У 18 - 19 ст. китайські музиканти уже використовують європейські інструменти та виконують європейські музичні твори. Зміни відбуваються і у вокальному мистецтві, де з'явилась так звана музична форма - таньци.

У 20 ст. формується китайська професійна музика, розвивається система музичної освіти. Відбуваються пошуки в музичній стилістиці з метою підкреслення національної основи. Китайські композитори в оригінальних творах поєднують національно-стилістичні витоки з моделями європейської музики, чим створюють свій національно забарвлений стиль.

Ключові слова: світоглядна система Китаю; музичне мистецтво; культурні традиції; філософія країни. 


\section{ЭТАПЫ ФОРМИРОВАНИЯ МУЗЫКАЛЬНЫХ ТРАДИЦИЙ КИТАЯ}

Антошко Марина Олеговна

Кандидат искусствоведения, ORCID: 0000-0002-4105-7519, antoshko.m@rambler.ru, Национальная музыкальная академия Украины имени П. И. Чайковского, Киев, Украина

Целью статьи является анализ развития мировоззренческой системы древнего Китая, в частности философии, которая непосредственно определяла культурные и музыкальные традиции страны. Методология исследования заключается в использовании исторического и биографического методов в изучении данной тематики. Исследованы действия мировоззрения Древнего Китая на музыкальные традиции страны. Выделены исторические имена философов, оказавших наибольшее влияние на развитие музыкального искусства и образования, что также отразилось на культурных традициях.

Выводы. Доказано, что возникновению музыкальной культуры Китая содействовало выполнение ритуальных песенно-танцевальных обрядов во время работы, впоследствии она отразилась в придворных и храмовых традициях. Вследствие этого было создано Музыкальное ведомство, благодаря которому открыли музыкальную школу по подготовке музыки и танцев в эпоху Ранней (Западной) Чжоу (11 - 3 вв. до н. э.). Философское содержание музыка начала приобретать в эпоху Поздней (Восточной) Чжоу (770 - 256 гг. до н. э.), чему способствовало возникновение и распространение конфуцианства и даосизма. В эпоху Хань благодаря культурному влиянию Индии и других стран Ближнего Востока в Китае распространяется буддизм и появляются новые музыкальные инструменты.

В 6 - 7 вв. создаются музыкальные произведения для инструментов цинь и пипа, которые пишутся в форме диалогов, включающих песни и танцы; возрастает роль оркестровой партии. В течение 11 - 13 вв. музыкальные стили разделились на северный (героические настроения, семиступенчатые ладі) и южный (строгие правила композиции, пентатоничные лады). С 17 в. китайская музыка становится народнопесенной. Приобретают популярность театрально-сценические представления - цзинцзюй. Значительное развитие получает оркестровое музицирование - ши фань ю. В 18 - 19 вв. китайские музыканты уже используют европейские инструменты и исполняют европейские музыкальные произведения. Изменения происходят и в вокальном искусстве, где появилась так называемая музыкальная форма - таньцы.

В 20 в. формируется китайская профессиональная музыка, развивается система музыкального образования. Происходят поиски в музыкальной стилистике с целью подчеркивания национальной основы. Китайские композиторы в оригинальных произведениях сочетают национально-стилистические истоки с моделями европейской музыки, чем создают свой национально окрашенный стиль.

Ключевые слова: мировоззренческая система Китая; музыкальное искусство; культурные традиции; философия страны. 